University of Nebraska - Lincoln

DigitalCommons@University of Nebraska - Lincoln

2004

\title{
Social Play in Kaka (Nestor meridionalis) with Comparisons to Kea (Nestor notabilis)
}

Judy Diamond

University of Nebraska - Lincoln, jdiamond1@unl.edu

Alan B. Bond

University of Nebraska - Lincoln, abond1@unl.edu

Follow this and additional works at: https://digitalcommons.unl.edu/bioscibehavior

Part of the Behavior and Ethology Commons

Diamond, Judy and Bond, Alan B., "Social Play in Kaka (Nestor meridionalis) with Comparisons to Kea (Nestor notabilis)" (2004). Papers in Behavior and Biological Sciences. 34.

https://digitalcommons.unl.edu/bioscibehavior/34

This Article is brought to you for free and open access by the Papers in the Biological Sciences at DigitalCommons@University of Nebraska - Lincoln. It has been accepted for inclusion in Papers in Behavior and Biological Sciences by an authorized administrator of DigitalCommons@University of Nebraska - Lincoln. 


\title{
Social Play in Kaka (Nestor meridionalis) with Comparisons to Kea (Nestor notabilis)
}

\author{
Judy Diamond \\ University of Nebraska State Museum, \\ University of Nebraska-Lincoln, Lincoln, NE 68588, USA \\ Alan B. Bond \\ School of Biological Sciences, \\ University of Nebraska-Lincoln, Lincoln, NE 68588, USA \\ Corresponding author-J. Diamond, jdiamond@unl.edu
}

\begin{abstract}
Summary
Social play in the kaka (Nestor meridionalis), a New Zealand parrot, is described and contrasted with that of its closest relative, the kea (Nestor notabilis), in one of the first comparative studies of social play in closely related birds. Most play action patterns were clearly homologous in these two species, though some contrasts in the form of specific play behaviors, such as kicking or biting, could be attributed to morphological differences. Social play in kakas is briefer, more predictable, and less sequentially diverse than that shown by keas. Kaka play also appears to be restricted to fledglings and juveniles, while the behavior is more broadly distributed among age groups in keas. Play initiation behaviors were relatively more frequent in kakas and more tightly intercorrelated in occurrence. A primary grouping of action patterns in kakas consisted of arboreal play, which was rare in keas. The most striking species difference was exhibited in social object play, which is pervasive among keas, but which was not observed in kakas. Although the two species are morphologically similar, they differ strikingly in several aspects of their ecology and social behavior, including the duration of the association between juveniles and adults, the degree of exploratory behavior,

This work was supported in part by the National Geographic Society, the University of Nebraska State Museum, and the University of Nebraska School of Biological Sciences. Research was conducted under permits from the Southland, Canterbury, and Westland Conservancies of the New Zealand Department of Conservation. The authors thank P. Simpson for his assistance and support at Arthur's Pass National Park, Drs. G. Elliott and R. Moorhouse for their ongoing assistance and collaboration, R. Tindal for his insights into kaka behavior, and H. and I. Broughton for permission to access their kaka field site. Dr. G. Paz-y-Miño C. and two anonymous reviewers for Behaviour provided us with thoughtful comments and valuable suggestions on an earlier version of the manuscript. B. and R. Bond assisted in videotaping, still photography, and collection of field data.
\end{abstract}


and the flexibility of their foraging strategies. The observed species differences in play behavior are discussed in relation to the contrasting life histories in the two species, suggesting that many features of social play may reflect evolutionary responses to particular ontogenetic and ecological constraints.

\section{Introduction}

Comparative studies of play have provided much of the basis for our current understanding of the functional significance of social play (Ewer, 1973; Fagen, 1981; Bekoff, 1984; Bekoff \& Beyers, 1998). Because social play is rarer among birds than among mammals, comparative studies of avian play have been relatively uncommon (Fagen, 1981; Ortega \& Bekoff, 1987; Diamond \& Bond, 2003). Surveys of avian play suggest that it is associated with age of first reproduction and duration of the association between juveniles and adults (Diamond \& Bond, 2003), with altricial development (Ortega \& Bekoff, 1987; Power, 2000), with larger relative brain size (Ortega \& Bekoff, 1987; Heinrich \& Smolker, 1998; Diamond \& Bond, 2003), and with higher levels of sociality (Skutch, 1987; Collar, 1997).

This article compares social play in the kaka (Nestor meridionalis), a crow-sized parrot from New Zealand's temperate rainforest, to that of the kea ( $N$. notabilis), a congeneric montane species. Keas provide some of the best documented examples of social play of any bird (Potts, 1969; Keller, 1975; Diamond \& Bond, 1999, 2003), and the common view, until recently, was that keas were the only New Zealand parrot that engaged in social play (Diamond \& Bond, 1999). Moorhouse (personal communication), however, observed play between newly fledged birds in the immediate vicinity of the nest in a mainland population of kakas, and in 2001 and 2003, we observed social play among juvenile kakas on Stewart Island (Diamond \& Bond, 2002). In this article, we contrast the form and incidence of social play in these two species and relate the similarities and differences to aspects of their morphology, behavior, and ecology.

Although play has long been recognized in birds, it is not nearly as prevalent as it is in mammals (reviews in Fagen, 1981; Ortega \& Bekoff, 1987; Power, 2000). Play has been described in only ten avian orders (Fagen, 1981; Skeate, 1985; Ortega \& Bekoff, 1987), and in our review of social play in birds (Diamond \& Bond, 2003), we found only five avian orders in which there was unambiguous evidence of social play. Three 
of these, the parrots, corvids and babblers, showed evidence of such extensive social play as to be on a par with that of many groups of mammals. Within these orders, social play has been most extensively studied in keas, ravens (Corvus corax), Australasian magpies (Gymnorhina tibicen) and Arabian babblers (Turdoides squamiceps) (reviewed in Diamond \& Bond, 2003).

There is a well-established literature on the definition of play and the criteria by which it can be distinguished from other forms of social behavior (e.g. Bekoff \& Byers, 1981; Fagen, 1981; Barber, 1991; Bekoff, 1995; Pellis \& Pellis, 1996; Power, 2000; Burghardt, 2001; Spinka et al., 2001). Social play involves at least two individuals that interact with and respond to each other, it incorporates actions from a variety of contexts into labile temporal sequences, and the actions are often repeated by mutual initiative (Bekoff, 1974; Ficken, 1977; Fagen, 1981). The interactions in social play lack consummatory behaviors; thus, they are frequently not resolved, but rather are repeated until the play partners are distracted by other stimuli (Lorenz, 1956). Social play may include components that are facilitated, but facilitation alone does not constitute sufficient evidence for social play (Diamond \& Bond, 2003). Social play is characteristic of juvenile animals, but its incidence among different developmental stages varies across species and types of play (Bekoff, 1974; Fagen, 1981; Simmons \& Mendelsohn, 1993; Diamond \& Bond, 1999; Power, 2000). In this study, we categorized behaviors as constituting social play if they fell within the limits of the readily identified play categories described in Diamond \& Bond (2003): Play chasing, play fighting, play invitations, and social object play.

\section{Kea and kaka: a comparative behavioral system}

Keas and kakas appear to have evolved from a common ancestral form in the Pleistocene (Fleming, 1979) and are morphologically similar (Holdaway \& Worthy, 1993). The two species have, however, diverged behaviorally and ecologically, adopting strikingly different habitat preferences, foraging ecologies, and social systems. Kakas are found on all three of the main islands of New Zealand - the North Island, the South Island, and Stewart Island (Worthy \& Holdaway, 2002). In recent times, their numbers have been dramatically reduced on the North and South Islands as a consequence of habitat destruction and predation by introduced mammals. The healthiest remaining kaka populations are on offshore islands, including Stewart, Kapiti, Little Barrier, and Cod- 
fish (Moorhouse et al., 2003). In contrast, the geographic range of keas is restricted to mountainous areas of the South Island (Bond \& Diamond, 1992; Elliott \& Kemp, 1999; Worthy \& Holdaway, 2002).

Differences in the behavioral ecology of the two species are marked, particularly with respect to dietary breadth and neophobia. Keas feed on beech mast, berries, grubs and other insects, plant stems and roots, nectar, bird's eggs and nestlings, carrion, and in fact nearly anything edible that occurs in their habitat (Brejaart, 1988; Diamond \& Bond, 1999; Worthy \& Holdaway, 2002; Cuthbert, 2003). Their generalist foraging strategy is driven by an almost manic exploratory behavior, involving a level of attraction to novel stimuli that may well be unique among birds (Kubat, 1992; Ritzmeier, 1995). Kakas, in contrast, are relatively specialized foragers, feeding mainly on nuts, seeds, fruits, nectar, honeydew, and tree sap (O'Donnell \& Dilks, 1989; Moorhouse, 1995, 1997), along with a limited range of arboreal insects (Beggs \& Wilson, 1987). They are also highly neophobic, particularly as adults (Wilson et al., 1991).

Age and sex can generally be determined at a distance in these parrots. Fledgling and juvenile kakas are identifiable by a pale periophthalmic ring until they are nearly a year old, and as they age, their eye rings gradually fade. Females appear to retain eye-rings longer than males (Moorhouse et al., 1999). Keas are even more amenable to age categorization, displaying distinctive morphological features for up to four years after fledging (Diamond \& Bond, 1991). Adult females of both species have conspicuously shorter bills than males and are significantly smaller, though sex differences are less conspicuous and less reliable in younger birds (Bond et al., 1991; Moorhouse \& Greene, 1995).

As a consequence, the course of behavioral development of both keas and kakas is well understood, and the species show striking differences in their social biology. Kakas and keas both fledge at about ten weeks after hatching but continue to be fed directly by their parents for least another 5 to 6 weeks (Jackson, 1963a; Moorhouse, 1995). The major ontogenetic difference between the species is in their subsequent dispersal and sexual maturation. Juvenile kakas generally disperse from the natal area about 6 months after fledging; at one year, their coloration is similar to that of adults (Moorhouse \& Greene, 1995), and at two years female kakas can breed (Holland, 1999). Keas, in contrast, form into loose juvenile flocks after fledging, where they scrounge food that adults have located. Young keas are visually distinguishable from adults until they are 3 years of age, and they do not begin to breed until 
they are 3 to 4 years old (Jackson, 1963a). Social relationships between juvenile keas and conspecific adults are more persistent than those of juvenile kakas: they continue to interact with adults for a longer period of time and they are both physically and behaviorally distinct from adults for a longer period (Diamond \& Bond, 1991).

These developmental and ecological contrasts between kakas and keas suggest the possibility of differences in the frequency and structure of social play. Within two species that are both relatively large-brained and altricial, social play might be expected to be more extensive in the species that has a longer period of association between juveniles and adults (Ortega \& Bekoff, 1987; Pellis \& Iwaniuk, 2000; Diamond \& Bond, 2003), that has more extensive exploratory behavior (Vandenberg, 1978; Hall, 1998; Power, 2000), and that is more flexible, innovative and generalized in their foraging behavior (Fagan, 1981, 1982; Ortega \& Bekoff, 1987; Spinka et al., 2001). In contrast to keas, kakas associate with adults for a shorter time as juveniles, they are relatively neophobic, and they are less flexible and more specialized in their foraging behavior. Therefore, one might predict that juvenile kakas should play less frequently or persistently than keas (Diamond \& Bond, 1999).

\section{Method}

In 2001 and 2003, we observed the behavior of kakas that aggregated at a sugarwater feeder adjacent to a private residence in the village of Oban on Stewart Island. Below the feeder and extending to each side was a cultivated flower garden that sloped down away from the lawn, terminating in a thick growth of native forest, primarily tree fuchsia (Fuchsia excorticata), kamahi (Weinmannia recemosa), and tree ferns (Dicksonia spp.). In addition to the sugar water, kakas fed on both the flowers and fruits of the fuchsia and took nectar from the kamahi and most of the flowers in the garden. This was a well-established resource, in that kakas had been making use of the feeder during the spring months for at least ten years. The kaka population using the feeder was unbanded, but we were able to reliably identify about twenty individuals on the basis of unique patterns of erosion and fracture lines on their bills (Pepper, 1996). Several of these individually identified birds appeared to be local residents, in that they visited the feeder several times each day. One mated pair held territory in the tree ferns and tree fuchsia adjoining the feeder, giving song and aggressively asserting their priority at the resource. Several other mated pairs of recognizable individuals also made regular, but less frequent, use of the feeder, sometimes temporarily displacing the primary residents. The feeder was visited by up to 20 kakas at a time in 2001 and up to 13 in 2003 during the early morning and again during late afternoon and early evening. Over the course of 110 hours of observations at this site, we recorded 41 instances of social play among juvenile and fledgling kakas on the lawn below the feeder, on the top of tree ferns, and in the nearby tree fuchsia. 
Observations of kaka play behavior were contrasted to a database of records of kea play that we accumulated between 1988 and 1991 from a population at the Halpin Creek refuse dump, adjacent to Arthur's Pass National Park (Diamond \& Bond, 1991, 1999; Bond \& Diamond, 1992). Additional observations of kea play were made during the spring of 2000 at a refuse dump near Fox Glacier in Westlands National Park. From these studies, totaling over 450 hours of observation, we obtained 21 instances of kea social play on open ground, on piles of rock scree, or among beech trees surrounding the refuse dumps. Both settings offered numerous objects that could potentially be incorporated into play. The garden on Stewart Island was littered with shells, small stones, sticks of all sizes, and pieces of flowers. The refuse dump at Arthur's Pass and Fox Glacier contained many similar small objects, ranging from food containers and pieces of plastic to bones, stones, sticks, and flowers.

Instances of play in both species were generally recorded on video (18 instances for kakas; 3 for keas), as time-event sequences on a computer-based event recorder (8 instances for keas), or documented in detailed, written field notes (23 instances for kakas; 10 for keas). Each play instance consisted of one or more bouts. A bout was defined as beginning with the first recognizable play behavior, usually a play invitation, and terminating when the individuals separated, either when there was a pause in the action long enough for the birds to begin to engage in other behaviors or as a result of one of the play partners' leaving the area. When a pair of birds terminated a play bout by engaging in other behaviors for up to two minutes and then subsequently resumed social play, they were recorded as beginning a new bout within the same play instance.

We constructed ethograms of the play repertoire of each species, and we recorded the time of day and duration for each play bout, which we subsequently analyzed for species differences. To avoid biased sampling, we used only the time of the first bout in each play instance in the analysis of time of day. For both measures, the distributions violated the assumptions of parametric analysis, so we used Wilcoxon two-sample comparison tests. Because play bouts were recorded using a variety of techniques that differed in their data resolution, we converted all results to a check-sheet format using one-zero encoding, recording the presence or absence of each action pattern in each bout. One-zero encoding has commonly been used in studies of primate behavior (e.g. Kraemer, 1979; Singh, 1989), and it appears to yield acceptable frequency estimates, provided that the sampling intervals are sufficiently brief (Tyler, 1979; Rhine \& Linville, 1980; Zinner et al., 1997). Using Fisher's exact probability tests, we tested each action pattern for species differences in the proportion of bouts in which it was observed. At the suggestion of a reviewer, we conducted additional analyses of the relationship between bout duration and repertoire size (that is, the number of different action patterns observed in a given bout), using Spearman signed-ranks tests.

Finally, to compare the structure of play interactions in the two species, we conducted a cluster analysis of the two species' event matrices. Presence/absence data is particularly well suited to cluster analysis, commonly producing robust and readily interpretable data structures (e.g. Cassini \& Vila, 1990; Diamond \& Bond, 1999). The array of presence/absence data (behaviors $\times$ bouts) for each species was converted to a similarity matrix using the cumulative hypergeometric technique developed by $\mathrm{Li}$ \& Dubes $(1984,1989)$. In this approach, a similarity index between pairs of behavioral variables is estimated by computing the probability of obtaining no more than the ob- 
served number of matches, if the entries in the respective columns of the sample matrix were randomly permuted. The hypergeometric similarity index is a kind of correlation coefficient for binary data, in that it provides a direct, concrete measure of the statistical confidence in the degree of association between two action patterns. We implemented Li and Dubes' technique in C, using Wu's (1993) prime factorization algorithm to obtain fast, accurate values for the hypergeometric distribution and a sieve algorithm from Luo (1989) to compute vectors of primes. Similarity matrices were subsequently converted to cluster structures using oblique principal component cluster analysis (SAS VARCLUS procedure) and displayed as hierarchical trees.

\section{Results}

Most of the action patterns we observed in kaka play have previously been described in keas (Potts, 1969; Keller, 1975; Diamond \& Bond, 1991), though the form and context of the behaviors often differed (Table 1). Social play in kakas was typically crepuscular, occurring either just before dawn or, more commonly, in the evening between 1800 and 2200. The median time of day from 41 instances of kaka play was 2024 , and fewer than $15 \%$ of the observations were in the morning hours. In contrast, the median time of day from 21 instances of kea play was 16:00, and over $40 \%$ of the observations were made from the morning hours. This species difference was statistically significant $\left(W^{+}=369, Z=-4.34, p<0.0001\right)$.

The social context of play interactions showed clear species differences. All kakas that we observed in active social play were juveniles or fledglings. It is possible that birds without eye rings are not recognized as appropriate play partners. One male kaka with no visible eye ring repeatedly tried to solicit play from other juveniles and several times interjected himself into ongoing play bouts between other birds. Respondent individuals treated the non-ringed bird's actions as aggressive, however, and fled from him. This was in striking contrast to our observations of kea play, in which fully $25 \%$ of the participants were subadults or adult females. In addition, play was invariably a pair activity in juvenile kakas. The presence of actively playing juveniles appeared to attract others - in over 19\% of kaka play instances, as many as three other young birds watched the playing pair - but the facilitated individuals were only rarely able to break into an ongoing play interaction and exchange places with the active participants. Keas also primarily played in pairs, but our kea data set included three instances ( $14 \%$ of the total) of social play among three or four active participants, something we never observed in kakas. 
Table 1. Comparisons of form and frequency in kaka and kea play behaviors

\begin{tabular}{lll}
\hline Behavior & Occurrence in kaka & Comparison to kea \\
\hline Bite attempt & $\begin{array}{l}\text { Kakas use their bill to surround } \\
\text { another's body part and gen- } \\
\text { tly and briefly hold it. The part- } \\
\text { ner does not react to this as if pain } \\
\text { were inflicted. Painful bites were } \\
\text { an infrequent component of play } \\
\text { in kakas. }\end{array}$ & $\begin{array}{l}\text { Bites were a common compo- } \\
\text { nent of play in keas. We ob- } \\
\text { served keas in play repeatedly } \\
\text { grabbing a part of another indi- } \\
\text { vidual particularly the tail, feet, } \\
\text { or legs with their bills, and the } \\
\text { partner reacts by vocalizing or } \\
\text { by jerking away indicating that } \\
\text { some pain may have been in- } \\
\text { flicted (Diamond \& Bond, 1999; } \\
\text { Keller, 1976). }\end{array}$ \\
&
\end{tabular}

$\begin{array}{ll}\text { Head cock } & \text { Kakas frequently turn their head } \\ \text { on one side while looking at or ap- } \\ \text { proaching another in play. Often } \\ \text { the head turning movement is ex- } \\ \text { treme, resulting in the head being } \\ \text { nearly upside down. This behavior } \\ \text { is conspicuous at the onset of play } \\ \text { interactions and often leads to roll- } \\ \text { ing over. }\end{array}$

Keas sometimes initiate play by approaching another while head cocking, but it is not as conspicuous as in kakas.

$\begin{array}{ll}\text { Wing flap } & \text { A kaka rapidly flaps its out- } \\ \text { stretched wings, usually while } \\ \text { standing on another bird's stom- } \\ \text { ach or while hanging upside-down } \\ \text { from a tree branch. This also oc- } \\ \text { curs during play on the ground in } \\ \text { kakas that are attempting to main- } \\ \text { tain their position on top of a su- } \\ \text { pine partner. }\end{array}$

Keas that are trying to keep their balance on a supine partner use wing flaps, but they also engage in mutual jumping and wing flapping as a separate, distinctive component of social play.

Foot push Kakas engage in mutual foot pushing as one of the most common features of their social play. This typically occurs while one bird is standing on another's stomach while it is lying on its side next to partner or while it is hanging upside down next to another. Kakas sometimes grasp a partner with one foot to attempt to draw them back into a play interaction.

Keas engage in vigorous mutual foot pushing, most commonly from a standing position. Keas sometimes fly over another bird and hit them with their feet. 
Table 1. (cont.) Comparisons of form and frequency in kaka and kea play behaviors

\begin{tabular}{lll}
\hline Behavior & Occurrence in kaka & Comparison to kea \\
\hline Hang & $\begin{array}{l}\text { Kakas frequently hang from a } \\
\text { branch by the bill or by one or } \\
\text { both feet with head and body } \\
\text { upside-down, sometimes flap- } \\
\text { ping the wings. It occurs during } \\
\text { social play, during solitary dis- } \\
\text { plays of hanging when they de- } \\
\text { molish vegetation and vocalize } \\
\text { loudly, and also as a component } \\
\text { of locomotion during foraging. }\end{array}$ & $\begin{array}{l}\text { Keas sometimes hang during so- } \\
\text { cial play and as a component of } \\
\text { ingeral locomotion during forag- } \\
\text { ing attempting to knock him off } \\
\text { (Diamond \& Bond, 1999). }\end{array}$ \\
\hline $\begin{array}{l}\text { Kakas hop by moving to or from } \\
\text { another bird along the ground } \\
\text { using both feet simultaneously in } \\
\text { short bouncy movements. Such } \\
\text { oblique, bouncy hops are often a } \\
\text { means of soliciting of maintain- } \\
\text { ing play. }\end{array}$ & $\begin{array}{l}\text { Keas often hop toward other } \\
\text { birds during play, but less often } \\
\text { as a prelude to it. Hopping often } \\
\text { accompanies vertical tossing of } \\
\text { objects in play interactions. }\end{array}$ \\
\hline $\begin{array}{l}\text { Kakas repeatedly jump on the } \\
\text { stomach of a supine partner as } \\
\text { part of play. They also jump over } \\
\text { another bird, and sometimes } \\
\text { jump in the air next to a play } \\
\text { partner. Kakas jump and wing } \\
\text { flap in play, but we did not ob- } \\
\text { serve them to do this in unison } \\
\text { or repeatedly. }\end{array}$ & $\begin{array}{l}\text { Keas often jump on the stom- } \\
\text { ach on a supine partner as part of } \\
\text { play (Potts, 1969). They also jump } \\
\text { over another bird, and sometimes } \\
\text { in the air next to a play partner. } \\
\text { Keas engage in repeated mutual } \\
\text { jumping and wing flapping as a } \\
\text { major component of social play. }\end{array}$ \\
\hline
\end{tabular}

Bill lock Kakas sometimes touch their bills to each other very briefly in play. In aggression touching bills is a common display. Locking and twisting bills was very seldom observed in kakas.
A kea bill locks by grasping the other's maxilla in its bill, twisting and pushing, using its own body weight for leverage (Keller, 1975). This behavior is a common feature of kea play.

$\begin{array}{ll}\text { Manipulate } & \text { Kakas sometimes grasp tree } \\ \text { object } & \text { fronds or branches in their bill } \\ & \text { while playing in trees or tree } \\ & \text { ferns, but they do not appear to } \\ & \text { manipulate these or other objects } \\ & \text { in the course of their play. }\end{array}$

Keas often pick up small rocks, pieces of paper, or other small objects on the ground in the course of a play interaction. They will also try to grasp an object with their bill that is already being held by another kea, resulting in a tug-of-war or a chase to retrieve the object. Object play is a very common component of kea play. 
Table 1. (cont.) Comparisons of form and frequency in kaka and kea play behaviors

\begin{tabular}{|c|c|c|}
\hline Behavior & Occurrence in kaka & Comparison to kea \\
\hline Roll over & $\begin{array}{l}\text { In play, a kaka rolls its entire body } \\
\text { over and lies on its back while gen- } \\
\text { tly moving its feet. The roll may be- } \\
\text { gin with turning the head or wing } \\
\text { under. When it begins with the } \\
\text { head, the action may produce a } \\
\text { somersault or sideways roll. When } \\
\text { it begins with the wing, the action } \\
\text { ends with the bird lying on its back. } \\
\text { Kakas roll over on their backs and } \\
\text { wave their feet in the air as a ma- } \\
\text { jor component of play interactions. } \\
\text { In kakas, rolling over often follows } \\
\text { from a head cock. }\end{array}$ & $\begin{array}{l}\text { Keas perform a virtually identi- } \\
\text { cal action pattern as kakas, rolling } \\
\text { over on their backs and waving } \\
\text { their feet in the air, as a compo- } \\
\text { nent of play interactions. }\end{array}$ \\
\hline Toss & $\begin{array}{l}\text { Tossing was not observed in kakas } \\
\text { during play or in any other context. }\end{array}$ & $\begin{array}{l}\text { In play, a kea typically holds an } \\
\text { object in its bill and then jerks the } \\
\text { head vertically, releasing the ob- } \\
\text { ject in the air, sometime in the di- } \\
\text { rection of the play partner. The } \\
\text { bird may also hop or flap its } \\
\text { wings just before releasing the ob- } \\
\text { ject (Potts, 1969). It may persist in } \\
\text { tossing the object for several min- } \\
\text { utes. Tossing occurs in keas as a } \\
\text { component of solitary play, social } \\
\text { play between juveniles and court- } \\
\text { ship play between adults (Dia- } \\
\text { mond \& Bond, 1999). }\end{array}$ \\
\hline
\end{tabular}

Kaka play occurred in bouts of intense interaction, each of them typically of 20-30 seconds duration. We recorded seven extended play interactions, involving multiple successive bouts, but even these rarely lasted longer than three minutes in total. Bouts of social play in keas generally lasted longer than bouts in kakas. The median duration of 55 bouts of kaka play was 27 seconds (interquartile range $=48.5$ ); that of 28 bouts of kea play was 48 seconds (interquartile range $=60$ ). This difference was significant $\left(W^{+}=1438.5, Z=2.53, p<0.015\right)$. The size of the displayed play repertoire increased significantly with bout length in kakas (Spear$\operatorname{man} r=0.52 ; p<0.001)$. This is due to the finding that all bouts, irrespective of length, were equally likely to include the two initiation behaviors, Head Cock and Roll Over. The remaining kaka play action patterns were 
Table 2. Percentage of play bouts including one or more occurrences of the specified action pattern

\begin{tabular}{lccc}
\hline Behavior & Kea & Kaka & Significance \\
\hline Bite Attempt & 60.71 & 67.27 & NS \\
Head Cock & 10.71 & 61.82 & $* *$ \\
Wing Flap & 82.14 & 87.27 & NS \\
Foot Push & 71.43 & 69.09 & NS \\
Hang & 3.57 & 36.36 & $* *$ \\
Hop & 53.57 & 56.36 & NS \\
Jump & 82.14 & 56.36 & $*$ \\
Bill Lock & 35.71 & 1.82 & $*$ \\
Manip Object & 21.43 & - & \\
Roll Over & 39.29 & 69.09 & $*$ \\
Toss & 10.71 & - & \\
\hline
\end{tabular}

The table is based on samples of 55 bouts from kakas and 28 from keas. Dashes indicate that the behavior was not observed in the given species. Significance of species differences were tested with Fisher's exact tests: ${ }^{*}=p<0.01{ }^{*}{ }^{*}=p<0.05$; NS = not significant.

more commonly exhibited in longer bouts $\left(W^{+} \geq 112, Z \geq 2.11, p<0.04\right)$. This effect was not shown in keas (Spearman $r=0.23 ; p>0.2$ ).

Head cocking and rolling over appeared to serve not only to initiate play, but also to reinstate play after brief pauses or disruptions. Soliciting or initiating kakas typically approached their play partners while cocking their heads to one side and performing a series of small, bouncy hops. When this occurred on the ground, the torsional movement of the head often extended into the body, to the point that the soliciting bird would lie down on one side. Continuation of the movement usually rolled the soliciting bird over on its back, where it continued to look at its prospective play partner while waving its feet in the air (Table 1).

Play invitations generally took similar forms in both species, in that keas and kakas both performed a distinctive, hopping approach to a prospective play partner. Both species also often displayed a head cock at the onset of a play interaction and used rolling over as a means of soliciting initiation or resumption of social play. Kakas, however, showed a significantly higher incidence of Head Cock and Roll Over (Table 2). Indeed, roughly $60 \%$ of kaka play interactions began with one or both of these action patterns. Play initiation in keas appeared to be more variable; many kea interactions proceeded directly from a hopping ap- 
proach to active play fighting without additional invitation. Keas in captivity may show other forms of play invitation (Keller, 1975), but we did not observe these in wild populations (Diamond \& Bond, 1999).

Kaka play invitations typically led to episodes of play fighting. If the potential play partner was responsive, it approached the soliciting individual that was lying on its back and jumped on its stomach with both feet while vigorously flapping its wings. The wing-flapping appeared to function mainly to maintain balance, rather than to strike at the play partner. Both partners then pushed and wrestled with their feet while feinting at each other with partially opened bills. The frequency of bite attempts did not differ between kakas and keas (Table 2). Kakas, however, seldom appeared to bite down hard enough to inflict pain; kakas that are bitten generally continued to play, as if the bite was not particularly important. Keas, in contrast, often bit each other strongly during play, grabbing their partner by the tail, feet, or legs with their bills and sometimes even dragging the partner across the ground (Diamond \& Bond, 1999); keas that are bitten in the course of play often flinch noticeably, suggesting that the bite is at least aversive.

Play fights in kakas and keas also showed many similar action patterns, but they were combined in strikingly different sequences. Kaka play fights consisted mainly of repeated episodes of one individual rolling over on his back while the partner jumps on his stomach, with ensuing mutual wing flapping, bite attempts, and foot pushes. Although keas also were observed to roll over and jump on each other's stomachs, their play sequences commonly included other actions taken while standing, including bite attempts, foot pushes, and bouts of simultaneous jumping and wing flapping. Both species incorporated some vertical jumps and wing flaps into their play sequences, but one of the most characteristic features of kea play consisted of extended sequences in which the two birds stood facing each other breast to breast and simultaneously hopped up and down while vigorously flapping their wings. This behavior was only very rarely exhibited in kakas. As a consequence, keas showed a significantly higher incidence of Jump (Table 2).

Play fighting also differed in keas and kakas with respect to their use of wrestling with the bill and pushing with the feet. Kakas rarely locked bills with one another during play, but a substantial portion of kea play involved bill locking, twisting, and wrestling using the bill, bouts that persisted even while one bird was standing on the stomach 
of the other (Table 2). The use of the feet in play fighting also showed differences between the species. Keas kicked each other while standing or in flight, while kakas were more likely to foot push while in close contact, either while hanging together upside down from branches or while rolling together on the ground.

Kaka play bouts often terminated with the responding bird simply stepping off his partner, though the partner would often cling to him with one foot, apparently in an effort to draw him back into further interactions. When the birds separated, the initiator usually stood up and looked around, and a brief pause in activity followed, often including grooming movements. Sometimes a new bout followed and the initiator hopped over to the partner and solicited again, cocking his head and rolling on his back. Occasionally, both birds would solicit simultaneously, both rolling over on their backs and reaching out to each other with their feet. Partners sometimes reversed their roles: The respondent bird was pushed off or fell off, he rolled onto his back, and the initiator then jumped on his partner's stomach. These reversals sometimes occurred multiple times in the same play bout.

While playing in trees and on the top of tree ferns, kakas hung upside down next to each other, usually by one foot, while vigorously flapping their wings. They then attempted to bite or to push each other with their free foot until one of them was forced to release his hold on the branch and fall out of the tree. Often, both participants fell and crashed through the branches together. On more level platforms, such as the tops of tree ferns, they rolled over and climbed onto each other's stomachs, much as they did on the ground. Jackson (1963b) reported play chases among adult and juvenile kakas, noting that the behavior involved "flying fast, twisting and swerving though the forest." We never observed play chasing among the birds on Stewart Island, however, and we saw reciprocal social play only between juveniles.

Keas, like kakas, at least occasionally played socially in trees, but the behavior generally took a different form. The arboreal play of kakas almost always involved hanging upside down, and although we have observed hanging in keas, it occurred significantly less frequently (Table 2). Arboreal play in keas, when it did occur, was usually confined to bill wrestling and foot pushes while sitting on branches or on the top of tree ferns. Rarer, more vigorous forms of arboreal play in keas generally involved jumping on each other and biting the feet of the play partner, forcing him to let go and drop to a lower layer in the tree. 


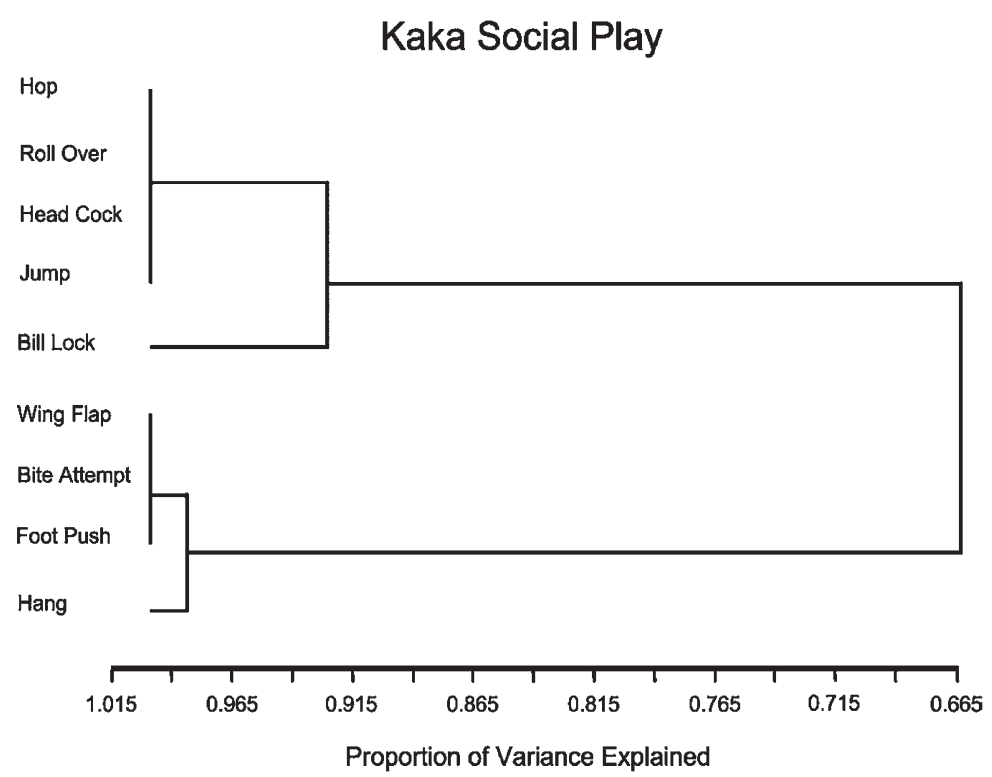

Figure 1. Cluster structure of action patterns from kaka play bouts, derived from oblique principal component cluster analysis.

Kakas apparently never incorporate objects in their social play. On Stewart Island, object manipulation among kakas revolved around plants, and most instances simply involved demolition. We watched individual kakas perching on digitalis flower stalks and pulling out and shredding the bright purple petals. While hanging upside from tree branches or fern fronds, kakas often ripped off fronds and leaves and dropped them to the ground in a continuous shower. Kakas did not manipulate objects in any social context, however, in spite of the fact that suitable small objects littered the site. This is one of the greatest differences we found between kaka and kea play. Keas manipulated objects wherever we observed them, and when they played socially, they incorporated the objects into their play. Both of the object-oriented behaviors in our ethograms - Toss and Manipulate Object-were common in keas and were never observed during play interactions in kakas (Table 2).

In our comparison of the cluster structures of play interactions in the two species, we found that $93 \%$ of the variation in kaka play behaviors was accounted for by two primary clusters, and the maximum second eigenvalue (an indicator of residual, unexplained variability) fell to 


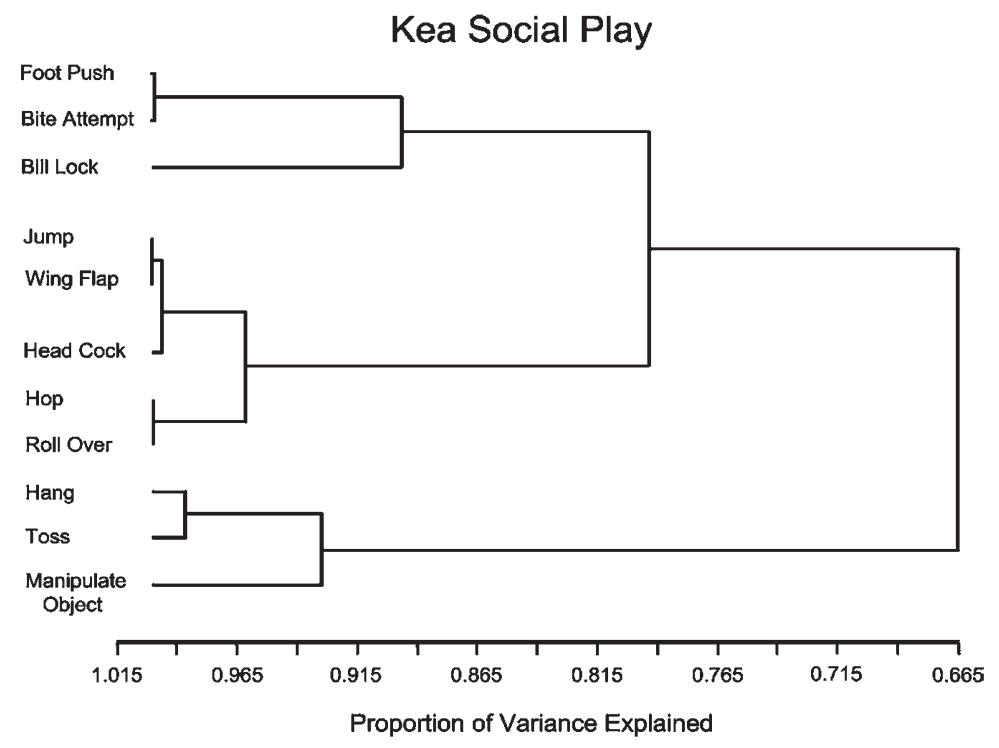

Figure 2. Cluster structure of action patterns from kea play bouts, derived from oblique principal component cluster analysis.

below 0.1 by the fourth cluster linkage. These results indicated a very compact and highly correlated cluster structure. When the results were displayed as a hierarchical tree (Figure 1), it was apparent that kaka play behavior segregated into two groupings, one mainly involved with play initiation behaviors and play on the ground (Hop, Roll Over, Head Cock, and Jump), and the other with play in the trees (Wing Flap, Bite Attempt, Foot Push, and Hang). Bill Lock was only observed once in our kaka play sample, so its cluster adherence was unreliable.

Keas, in contrast, required four primary clusters to account for $93 \%$ of the variation, and the maximum second eigenvalue did not drop below 0.1 until the seventh cluster linkage. These results indicated a much looser and more complex cluster structure. Displayed as a hierarchical tree (Figure 2), the kea results showed the direct contact action patterns (Foot Push, Bite Attempt, and Bill Lock) in one cluster, with a more distant linkage to a second grouping of action patterns indicative of largerscale movements and less direct contact (Jump and Wing-Flap as a tight association, along with Head Cock, Hop, and Roll Over). Actions involving social object play (Toss and Manipulate) collected in a third, virtually independent cluster. Hang was only observed once in our kea play sample, so its cluster adherence was unreliable. 


\section{Discussion}

The social play of kakas on Stewart Island is as robust and interactive as that of keas, and many of the action patterns appear to be homologous. Kakas and keas do, however, differ in the structure and context of their play behavior. Kakas play in smaller groups, they play in shorter bouts, and they are less likely than keas to play in the early morning. There were also striking differences between the species in the relative frequency of particular action patterns and in the correlational structure of play interactions. Ritualized play initiation behaviors, such as head cocking or rolling over, were relatively more frequent in kakas and clustered in a tighter, more coherent grouping. The other primary cluster of action patterns in kakas was dominated by arboreal play, which was relatively uncommon in keas. Keas generally showed a less tightly correlated behavior structure, with one cluster of intense, close-contact action patterns and another, looser collection of larger-scale movements and play initiation behaviors. Actions involving social object play collected in a third, virtually independent cluster for keas, but these were not observed in kakas at all.

The size of the displayed play repertoire increased significantly with bout length in kakas, something that was not observed in keas. Short bouts in kaka consist mainly of initiation behaviors, with long bouts displaying a larger portion of the repertoire. Keas exhibit a repertoire of behaviors that does not vary with bout length, suggesting greater variability in the sequence of action patterns. The implication of the cluster results, as well as the analysis of the relationship between repertoire size and bout duration, is that social play in kakas is in some ways more predictable and less sequentially diverse than that shown by keas.

Other species differences in play behavior may be dictated in part by differences in morphology. The frequency of bite attempts did not differ between the species. Kakas appeared less likely to grasp their play partners with their bills, seldom locking bills or biting down on legs or feathers. This may reflect a species difference in how hazardous a bite can be. Kakas have a powerful, shearing bill that can break open the toughest nuts and bark. Keas tend to grasp and twist or pry, rather than to crush or shear, and when they bite other keas, they do not generally draw blood. The contrast between keas and kakas in the use of the bill during play may, thus, be evolutionarily similar to the differences in aggressive behavior that Serpell (1982) observed among species of lori- 
keets, in which the birds with the most formidable weaponry were the least likely to use them in conspecific interactions.

Both species use their feet to push and kick at each other during fighting play, but keas are far more likely to kick their partner from a standing position. Again, this may be a morphological difference. Keas have much longer legs than kakas; the individual leg bones are $16-24 \%$ longer in keas than in the South Island kaka subspecies (Holdaway \&Worthy, 1993) presumably as an adaptation to foraging on the ground. It may be that kakas cannot readily stand on a level surface and kick forward. The absence in kakas of the mutual jumping and flapping that is a dominant element of kea play may also be a consequence of the kaka's primary adaptation to arboreal movement. During this display, keas generally hold their bodies and heads almost vertically while striking out with wings and feet, and it may not be possible for kakas to adopt the same erect stance.

In kakas, social play appears to be restricted to fledglings and juveniles, while play is much more broadly distributed among age groups in keas. Birds with a clearly adult appearance were not observed to participate in kaka play interactions, though we did see several instances of kakas that were morphologically adult unsuccessfully attempting to solicit play from younger birds. In contrast, we have commonly observed play between juvenile and subadult keas, and we recorded a number of instances of social play between adult females and younger birds. Keas also exhibit a separate, distinctive form of social play between adult or subadult males and females ('toss' play; Diamond \& Bond, 1999), which may be part of the process of courtship and pair formation. No such behavior was exhibited in our kaka population.

Perhaps the most striking difference between kea and kaka play is in their use of objects. Among keas, object play is a common component of both individual and group activities (Diamond \& Bond, 1999). A pair of fledglings will often contest for a single object, such as a stick, a stone, or a piece of cloth, pulling at it from both ends or repeatedly stealing it away from one another. That such interactions are actually play, rather than simple competitive aggression, is suggested by the fact that such object-oriented games often give way to active play fighting, leaving the contested object behind. A frequent type of object play in keas involves repeatedly tossing a small item in the air (Potts, 1969). We recorded keas tossing rocks, sticks, bottle caps, seed pods, walnuts and other small objects, particularly during play interactions between indi- 
viduals of opposite sexes (Diamond \& Bond, 1999). Solitary object play is pervasive, but it is also highly facilitative. One kea playing with an object will often attract several more, leading eventually to a group of young birds all excitedly tugging on the same item. We once observed a group of fledglings spend almost an hour pulling on a long piece of surgical gauze, walking around with it and periodically hopping, jumping, and pushing each other with their feet (Diamond \& Bond, 1999).

In contrast, kakas show less solitary object play - they are less likely to manipulate objects in any context not related to foraging - and we have never seen them use objects during social interactions. Unlike keas, kakas show no substantial interest in human artifacts or in objects that have no evident potential relationship to food. Groups of kakas rarely engage in simultaneous manipulation of an object, and although we sometimes observed two kakas next to each other in a tree fern both pulling out leaves and dropping them, their activities did not appear to be coordinated.

We observed both kakas and keas in the wild under conditions that were conducive to play: In both cases there were many juveniles present, they were generally satiated, and they were interacting in large social groups in close proximity to adults (Fagen, 1981; Garnetzke-Stollmann \& Franck, 1991). And the resulting social play in the two species showed striking similarities. Most play action patterns were clearly homologous: seven of the 11 behaviors were displayed by both species in recognizably similar forms. Phylogenetic relatedness may play a significant role in the incidence of social play, irrespective of the selective effects of other ecological and behavioral factors. This supports the suggestion from multi-species comparisons that play may be evolutionary primitive in the Psittaciformes, that given appropriate enabling conditions, most parrots will play (Diamond \& Bond, 2003).

Kakas and keas do exhibit a variety of significant differences in the structure and context of their social play, however. Kakas engage in play bouts that are shorter and less variable than those in keas, they play only during a more limited developmental period, and they do not display social object play. This suggests that ontogenetic and ecological factors, such as differences in the length of association of juveniles with adults, degree of exploratory behavior, or flexibility in foraging, may also influence the structure of social play.

Two conspicuous differences in the biology of these species may have been influential in determining the manifestation of their social 
play. First, young kakas remain in the presence of adults for a much shorter period than do keas (6 months vs. 2 years), and social play is commonly less extensive in species with more limited associations between juveniles and adults (Pellis \& Iwaniuk, 2000; Diamond \& Bond, 2003). Our observations provide some support for this interpretation, in that kaka play is less structurally complex than that of keas, and individual bout lengths are shorter.

Secondly, kakas are more neophobic and far less flexible and exploratory in their behavioral ecology than keas, and the occurrence of play behavior has often been linked to exploratory behavior (Vandenberg, 1978; Hall, 1998; Power, 2000), innovation (Fagan, 1982; Spinka et al., 2001), or ecological generality (Fagan, 1981; Ortega \& Bekoff, 1987). Although kakas do play socially, they do not engage in social object play, and it is this behavior that may show the strongest relationship to foraging flexibility. Social object play is relatively common among the larger Corvidae, suggesting that it may be related to their reliance on exploration and neophilia in foraging contexts, which is more characteristic of keas (Diamond \& Bond, 2003).

Our observations of these two parrot species provide one of the first comparative studies of social play in closely related birds. Further investigations will be needed to clarify the relative roles of phylogenetic relatedness and social or ecological factors in determining the manifestation of social play. Do more closely related birds generally have more similar play? Is greater behavioral flexibility commonly associated with more complex play? Only additional comparative studies can determine whether the relationships we have observed between play, life history strategies, ecology and behavioral flexibility in these two parrots can be generalized to other avian species.

\section{References}

Barber, N. (1991). Play and energy regulation in mammals. Q. Rev. Biol. 66, pp. 129-147.

Beggs, J. R. and Wilson, P. R. (1987). Energetics of South Island kaka (Nestor meridionalis meridionalis) feeding on the larvae of kanuka longhorn beetles (Ochrocydus huttoni). New Zeal. J. Ecol. 10, pp. 143-147.

Bekoff, M. (1974). Social play and play-soliciting by infant canids. Am. Zool. 14, pp. 323- 340.

- (1984). Social play behavior. Bioscience 34(4), pp. 228-233.

(1995). Play signals as punctuation, The structure of social play in canids. Behaviour 132, pp. 419-429. 
Bekoff, M. and Byers, J. A. (1981). A critical reanalysis of the ontogeny and phylogeny of mammalian social and locomotor play: an ethological hornet's nest. In: Behavioral development: The Bielefield interdisciplinary conference (K. Immelmann, G. Barlow, L. Petrinovich, and M. Main, eds.). Cambridge University Press, New York, pp. 296-337.

—_ and (eds. ) (1998). Animal play: evolutionary, comparative and ecological perspectives. - Cambridge University Press, Cambridge.

Bond, A. B. and Diamond, J. (1992). Population estimates of kea in Arthur's Pass National Park. Notornis 39, pp. 151-160.

_ , Wilson, K. J., and Diamond, J. (1991). Sexual dimorphism in the kea, Nestor notabilis. Emu 91, pp. 12-19.

Brejaart, R. (1988) Diet and feeding behaviour of the kea (Nestor notabilis). MS thesis Lincoln University, Canterbury, New Zealand.

Burghardt, G. M. (2001). Play attributes and neural substrates. In: Handbook of behavioral neurobiology Vol. 13 (E. Bass, ed. ). Kluwer Academic/Plenum Publishers, New York, pp. 317-356.

Cassini, M. H. and Vila, B. L. (1990). Cluster analysis of group types in southern right whale, Eubalena australis. Marine Mammal. Sci. 6, pp. 17-24.

Collar, N. J. (1997). Family Psittacidae (Parrots). In: Handbook of birds of the world, Vol. 4: Sandgrouse to Cuckoos (J. del Hoyo, A. Elliott and J. Sargatal, eds.). Lynx Edicions, Barcelona, pp. 280-477.

Cuthbert, R. (2003). Sign left by introduced and native predators feeding on Hutton's shearwaters Puffinus huttoni. NZ J. Zool. 30, pp. 163-170.

Diamond, J. and Bond, A. B. (1991). Social behavior and the ontogeny of foraging in the kea (Nestor notabilis). - Ethology 88, pp. 128-144.

- and (1999). Kea, bird of paradox, the evolution and behavior of a New Zealand parrot. University of California Press, Berkeley, CA.

$\longrightarrow$ and (2002). Play in parrots. Interpretive Birding 3, pp. 56-57. and - (2003). A comparative analysis of social play in birds. Behaviour 140, pp. 1091-1115.

Elliott, G. and Kemp, J. (1999). Conservation ecology of kea (Nestor notabilis). WWF-NZ Final report. World Wildlife Fund for Nature, New Zealand.

Ewer, R. F. (1973). The carnivores. Comstock Pub. Co., Ithaca, NY.

Fagen, R. (1981). Animal play behavior. Oxford University Press, New York.

- (1982). Evolutionary issues in development of behavioral flexibility. In: Perspectives in Ethology Vol. 5 (P. P. G. Bateson and P. H. Klopfer, eds.). Plenum Press, New York, pp. 365-383.

Ficken, M. S. (1977). Avian play. Auk 94, pp. 573-582.

Fleming, C. A. (1979). The geological history of New Zealand and its life. Auckland University Press, Auckland.

Garnetzke-Stollmann, K. and Franck, D. (1991). Socialization tactics of the spectacled parrotlett (Forpus conspicillatus). Behaviour 119, pp. 1-29.

Hall, S. L. (1998). Object play by adult animals. In: Animal play: Evolutionary, comparative and ecological perspectives (M. Bekoff and J. A. Byers, eds.). Cambridge University Press, Cambridge, pp. 45-60.

Heinrich, B. and Smolker, R. (1998). Play in common ravens (Corvus corax). In: Animal play: Evolutionary, comparative and ecological perspectives (M. Bekoff 
and J. A. Byers, eds.). Cambridge University Press, Cambridge, pp. 27-44.

Holdaway, R. and Worthy, T. H. (1993). First North Island fossil record of kea, and morphological and morphometric comparison of kea and kaka. Notornis 40, pp. 95-108.

Holland, G. (1999). Kaka breeding at Mt Bruce. OSNZ Supplement, Notornis 46(1), p. 1.

Jackson, J. R. (1963a). The nesting of keas. Notornis 10, pp. 319-326. (1963b). Studies at a kaka's nest. Notornis 10, pp. 168-176.

Keller, R. (1975). Das Spielverhalten der Keas (Nestor notabilis Gould) des Zürcher Zoos. Z. Tierpsychol. 38, pp. 393-408.

Kraemer, H. C. (1979). One-zero sampling in the study of primate behavior. Primates 20, pp. 237-244.

Kubat, S. (1992). Die Rolle von Neuigkeit, Andersartigkeit, und sozialer Struktur für Die Exploration von Objekten beim Kea (Nestor notabilis). PhD dissertation, Universität Wien, Vienna, Austria.

Li, X. and Dubes, R. (1984). Selection of significant dichotomous features. Proc. 7th Int. Conf. Pattern Recog. IEEE, New York, pp. 260-263. and (1989). A probabilistic measure of similarity for binary data in pattern recognition. Pattern Recognition 22, pp. 397-409.

Lorenz, K. Z. (1956). Plays and vacuum activities. L'Instinct dans le Comportment des Animax et de L'Homme (Autuori et al., eds.). Paris Fondation SingerPolignac, Masson et Cie, pp. 633-646.

Luo, X. (1989). A practical sieve algorithm for finding prime numbers. Comm. ACM 32: pp. 344-346.

Moorhouse, R. J. (1995). Productivity, sexual dimorphism and diet of North Island kaka (Nestor meridionalis septentrionalis) on Kapiti Island. PhD dissertation, Victoria University, Wellington, New Zealand.

(1997). The diet of the North Island kaka (Nestor meridionalis septentrionalis) on Kapiti Island. Notornis 21, pp. 141-152.

(Nestor meridionalis). Notornis 42, pp. 187-196.

— , Dilks, P., Powlesland, R., Moran, L., Taylor, G., Jones, A., Knegtmans, J., Wills, D., Pryde, M., Fraser, I., August, A., and August, C. (2003). Control of introduced mammalian predators improves kaka Nestor meridionalis breeding success: reversing the decline of a threatened New Zealand parrot. Biol. Cons. 110, pp. 33-44.

_ in the North Island kaka Nestor meridionalis septentrionalis: selection for enhanced male provisioning ability? - Ibis 141, pp. 644-651.

O'Donnell, C. F. J. and Dilks, P. J. (1989). Foods and foraging of forest birds in the temperate rainforest, South Westland, New Zealand. New Zeal. J. Ecol. 18, pp. 87-107.

Ortega, J. C. and Bekoff, M. (1987). Avian play: Comparative evolutionary and developmental trends. Auk 104, pp. 338-341.

Pellis, S. M. and Iwaniuk, A. N. (2000). Comparative analysis of the roles of postnatal development in the expression of play fighting in juveniles and adults. Dev. Psychobiol. 36, pp. 136-147. 
Pellis, S. M. and Pellis, V. C. (1996). On knowing it's only play: The role of play signals in play fighting. Agress. Violent Beh. 1, pp. 249-268.

Pepper, J. W. (1996). The behavioral ecology of the glossy black cockatoo Calyptorhynchus lathami halmaturinus. PhD dissertation, University of Michigan.

Potts, K. J. (1969). Ethological studies of the kea (Nestor notabilis) in captivity: Nonreproductive behavior. B. S. thesis. Victoria University, Wellington, New Zealand.

Power, T. G. (2000). Play and exploration in children and animals. Lawrence Erlbaum Assoc. Pubs., Mahwah, NJ.

Rhine, R. J. and Linville, A. K. (1980). Properties of one-zero scores in observational studies of primate social behavior: the effect of assumptions on empirical analyses. Primates 21, pp. 111-122.

Ritzmeier, M. (1995). The influence of hunger and low protein diet on exploration in keas (Nestor notabilis). M. Sc. thesis, Konrad Lorenz Institut für Vergleichende Verhaltensforschung, University of Vienna, Vienna, Austria.

Serpell, J. (1982). Factors influencing fighting and threat in the parrot genus Trichoglossus. Anim. Behav. 30, pp. 1244-1251.

Simmons, R. E. and Mendelsohn, J. M. (1993). A critical review of cartwheeling flights of raptors. Ostrich 64, pp. 13-24.

Singh, R. (1989). Ontogeny of aggressive and submissive behaviour in free living rhesus monkeys (Macaca mulatta). Proc. Indian Acad. Sci. (Anim. Sci. ) 98, pp. 139-148.

Skeate, S. T. (1985). Social play behaviour in captive white-fronted Amazon parrots Amazona albifrons. Bird Behav. 6, pp. 46-48.

Skutch, A. F. (1987). Helpers at birds' nests. University of Iowa Press, Iowa City, IA.

Spinka, M., Newberry, R. C., and Bekoff, M. (2001). Mammalian play: training for the unexpected. Quart. Rev. of Biol. 76, pp. 141-168.

Tyler, S. (1979). Time-sampling: a matter of convention. Anim. Behav. 27, pp. 801-810.

Vandenberg, B. (1978). Play and development from an ethological perspective. Am. Psych. 33, pp. 724-738.

Wilson, P. R., Toft, R. J., Shepard, C. A., and Beggs, J. R. (1991). Will supplementary feeding of South Island kaka improve breeding success? DSIR Land Resources Contract Report No. 91/55, Dept. of Conservation, New Zealand.

Worthy, T. H. and Holdaway, R. N. (2002). Lost world of the moa. Indiana University Press, Bloomington, IN.

$\mathrm{Wu}, \mathrm{T}$. (1993). An accurate computation of the hypergeometric distribution function. ACM Trans Math Software 19, pp. 33-43.

Zinner, D., Hindahl, J., and Schwibbe, M. (1997). Effects of temporal sampling patterns of all-occurrence recording in behavioural studies: many short sampling periods are better than a few long ones. Ethology 103, pp. 236-246. 